\title{
Pendidikan Kesehatan mengenai Deteksi Dini Depresi dan Penurunan Fungsi Kognitif pada lansia
}

\author{
Lynna Lidyana ${ }^{1}$ \\ Universitas Padjadjaran, llidyana@yahoo.com \\ Shelly ${ }^{2}$ \\ Universitas Padjadjaran, shelly@yahoo.com \\ Nita Fitria ${ }^{3}$ \\ Universitas Padjadjaran, nita_fitria2001@yahoo.com
}

\begin{abstract}
Abstrak
Prevalensi lansia (60-74 tahun) di Indonesia tahun 2050 diperkirakan melebihi prevalensi di dunia. Depresi pada lansia menempati urutan kedua setelah penyakit jantung coroner yang mempengaruhi morbiditas lansia. Peningkatan depresi pada lansia harus menjadi perhatian khusus semua elemen kesehatan agar berkontribusi maksimal dalam pelayanan preventif maupun kuratif. Fungsi kognitif secara bertahap akan menurun pada lansia seiring dengan bertambahnya usia. Kondisi depresi akan mempercepat penurunan fungsi kognitif lansia. Pengabdian Pada Masyarakat (PPM) ini bertujuan untuk melalukan pendidikan kesehatan mengenai deteksi dini depresi dan penurunan fungsi kognitif pada lansia. Realisasi pemecahan masalah untuk mendeteksi adanya gejala depresi dan penurunan fungsi kognitif pada lansia melalui kegiatan pendidikan kesehatan kepada semua eleman yang terkait di Balai Perlindungan Sosial Tresna Whreda (BPSTW) Ciparay Bandung. Elemen yang terkait meliputi pejabat panti, pramuwheda, perawat dan lansia. Setelah hasil pengkajian Mini Mental State Examination (MMSE) dan Geriatric Depression Scale (GDS-15) didapatkan 20 orang lansia depresi tingkat ringan dan sedang. Lansia yang mengalami depresi tingkat ringan dan sedang mendapatkan informasi mengenai gejala depresi dan bagi petugas panti,pramuwhreda mendapatkan informasi mengenai gejala umum yang dirasakan lansia ketika depresi dan upaya yang dapat dilakukan untuk mencegah terjadinya depresi. Perawat panti diberikan pelatihan dan pendampingan dalam menggunakan instrumen MMSE dan GDS-15. Kegiatan berlangsung sesuai rencana dan semua sasaran mengalami peningkatan partisipasi saat kegiatan penyuluhan berlangsung dan dilanjutkan dengan diskusi kecil diluar kegiatan penyuluhan.
\end{abstract}

Kata kunci: Deteksi dini depresi, Fungsi Kognitif, Pendidikan Kesehatan, Lansia

\begin{abstract}
The prevalence of elderly (60-74 years) in Indonesia in 2050 is estimated to exceed the prevalence in the world. Depression in the elderly ranks second only to coronary heart disease which affects elderly morbidity. Increased depression in the elderly must be of special concern to all health elements in order to contribute maximally in preventive and curative services. Cognitive function will gradually decrease in the elderly as we get older. Depression
\end{abstract}


conditions will accelerate the decline in cognitive function of the elderly. Community Service aims to carry out health education regarding early detection of depression and decreased cognitive function in the elderly. Realization of problem solving to detect symptoms of depression and decline in cognitive function in the elderly through health education activities to all related elements at the Balai Perlindungan Sosial Tresna Whreda (BPSTW) Ciparay Bandung. Related elements include officials of institutions, pramuwheda, nurses and the elderly. After the results of the Mini Mental State Examination (MMSE) and Geriatric Depression Scale (GDS-15) were obtained, 20 elderly people with mild and moderate depression. Elderly people who experience mild level depression and are getting information about symptoms of depression and for nursing staff, pramuwhreda get information about the common symptoms felt by the elderly when depression and the efforts that can be done to prevent the occurrence of depression. Nursing care providers are provided with training and assistance in using the MMSE and GDS-15 instruments. Activities take place according to plan and all targets experience increased participation when extension activities take place and proceed with a small discussion outside of extension activities.

Keywords: Early detection of depression, cognitive function, health education, Elderly

\section{Pendahuluan}

1. Latar Belakang Pengabdian

Prevalensi lansia di dunia sejak tahun 2013 mengalami peningkatan bahkan tahun 2050 prevalensi lansia di Indonesia lebih tinggi dibandingkan prevalensi di dunia (Kementrian Kesehatan RI,2016). Seiring dengan bertambahnya usia lansia ditemukan adanya penurunan derajat kebugaran jasmani. Penurunan derajat kebugaran jasmani pada usia 70 tahun sekitar 30-50\% (Bellingerand Minahan, 2015). Penurunan derajat kebugaran jasmani pada lansia yang relatif rendah disebabkan penurunan fungsi organ tubuh. Budaya masyarakat Indonesia berperan penting dalam menurunkan derajat kebugaran jasmani lansia, oleh karena budaya bangsa Indonesia sering membatasi aktivitas fisik sehari-hari dari lansia. Penurunan fungsi organ tubuh pada lansia menimbulkan peningkatan sumber energi dominan yang berasal dari metabolisme anaerobik. Metabolisme anaerobik dapat menyebabkan perubahan pada tingkat biomolekuler antara lain ekspresi protein plasma BDNF (Gorska, Saryusz, Borkowska, Ciebiada \& Loba, 2012).

Peningkatan prevalensi lansia menimbulkan berbagai permasalahan fisik dan psikologis oleh karena lansia mengalami penurunan secara fisiologis dan psikologis. Proses penurunan fisiologis dan psikologis tersebut menyebabkan lansia sulit untuk melakukan aktivitas fisik sehari-hari secara mandiri dan tergantung pada orang lain. Keterbatasan dalam melakukan aktivitas fisik sehari-hari dapat menimbulkan penurunan fungsi kognitif, timbulnya penyakit degeneratif, ketidakmampuan fisik, gangguan rasa nyeri, gangguan tidur, isolasi sosial. Keterbatasan lansia dalam melakukan aktivitas fisik sehari-hari menyebabkan lansia sulit beradaptasi dalam kondisi proses penuaan, merasa sendiri, frustasi, dan kehilangan kepercayaan diri sehingga timbul depresi yang mempengaruhi kualitas hidup lansia (Martinson and Berridge, 2016). 
Menurut Riset Kesehatan Dasar (2012) dan Njoto (2014), depresi merupakan salah satu gangguan suasana hati atau gangguan afektif. Seseorang yang mengalami depresi akan menyebabkan penurunan fungsi kognitif ,perubahan emosional, penurunan motivasi, penurunan fungsi dan perilaku motorik. WHO melaporkan penyakit depresi pada lansia menempati urutan kedua angka kesakitan setelah penyakit jantung koroner. Prevalensi depresi lansia diatas 60 tahun sekitar 10-20\%. Prevalensi depresi pada perempuan lansia sebesar 14,1 \% dan laki-laki lansia sebesar $8,6 \%$ dari total populasi (Darmojo,2014).

Menurut Irawan (2013) dan American Psychiatric Association (2015), faktor yang memengaruhi depresi pada lansia ialah faktor biokimia, faktor genetika, kepribadian dan lingkungan. Faktor lainnya yang memengaruhi depresi pada lansia adalah faktor demografi, dukungan keluarga, dukungan sosial dan kebutuhan spiritual (Bhayu,Ratep,Westa,2015). Faktor biokimia yang mempengaruhi depresi pada lansia, disebabkan adanya penurunan kadar neurotransmitter yaitu serotonin, epinefrin, dopamin yang terdapat di dalam otak yang menstimulasi terjadinya depresi.

Depresi pada lansia lebih sulit dideteksi, karena penyakit fisik pada lansia sering mengacaukan gambaran depresi. Manifestasi klinis depresi pada lansia berbeda dibandingkan depresi pada usia muda. Perasaan sedih, bersalah, kekhawatiran dan takut sering tidak muncul pada lansia. Gejala seperti gangguan tidur, cepat lelah, kehilangan minat hidup, sulit berkonsentrasi, tidak nafsu makan dan kehilangan harapan lebih sering ditemukan pada lansia penderita depresi. (Maurer, 2012 dan Hayashi, Decherrie, 2016). Sebagian besar gejala depresi pada lansia ditandai dengan penurunan kemampuan berfikir, sulit menangkap objek yang dilihat (Mura,2013). Lansia sebagian besar menutupi rasa sedihnya dengan menunjukkan kegiatan yang lebih aktif, padahal gejala depresi yang muncul sering ditutupi sehingga mengakibatkan meningkatnya prevalensi depresi pada lansia.

Pengukuran tingkat depresi pada lansia menggunakan instrumen Geriatric Depression Scale (GDS)-15 (Martinsol et al, 2009). Pengukuran fungsi kognitif menggunakan instrumen The Montreal Cognitive Assesment (MoCA), namun saat proses pengkajian instrumen ini tidak dapat dilakukan karena lansia di panti tidak mengalami mild dementia sehingga untuk mengukur fungsi kognitif digunakan instrumen Mini Mental State Examination (MMSE) (Lestari, Mistivani, Rumende, Kusumaningsih, 2017).

Akibat gejala depresi pada lansia lebih sulit dideteksi, karena penyakit fisik pada lansia sering mengacaukan gambaran depresi sehingga perlu adanya kegiatan penyuluhan mengenai pendidikan kesehatan mengenai deteksi dini depresi dan pengenalan perubahan fungsi kognitif (penurunan) pada lansia. Penyuluhan kesehatan perlu dilakukan kepada semua elemen yang ada di BPSTW Ciparay sehingga saling melengkapi dalam mensukseskan peningkatan kualitas hidup lansia di panti.

\section{Tujuan Pengabdian}

Tujuan kegiatan PPM adalah khalayak sasaran (semua elemen BPSTW Ciparay) memiliki peningkatkan partisipasi saat dilakukan penyuluhan kesehatan mengenai 
deteksi dini depresi dan penurunan fungsi kognitif pada lansia serta dapat mengaplikasikan kepada lansia di panti.

\section{Manfaat Pengabdian}

Manfaat yang ingin dicapai adalah diterapkannya pencegahan depresi dini pada lansia di panti melalui keterlibatan petugas panti dan pramuwhreda dan perawat yang mampu menggunakan instrumen MMSE dan GDS-15.

\section{4. $\quad$ Kajian Pustaka}

Penuaan adalah suatu proses alami yang tidak dapat dihindari. Proses penuaan menyebabkan perubahan anatomis, fisiologis, biokimia yang menyebabkan penurunan fungsi tubuh secara keseluruhan. (Sundari, Suhadi, Maryati, 2014). Perubahan anatomis pada lansia ditandai dengan penurunan jumlah sel, ukuran sel, cairan tubuh yang menurun khususnya cairan intraseluler. Selain itu ditemukan pula penurunan struktur sistem persarafan, endokrin, kardiovaskuler, respirasi, gastrointestinal, musculoskeletal, imunitas, panca indera, integumen, reproduksi, urinaria. Perubahan fisiologis ditandai dengan hilangnya kekuatan otot, gangguan sirkulasi, penurunan sistem kekebalan tubuh dan penurunan fleksibilitas sendi. Perubahan biokimia yang diprogram oleh molekul-molekul DNA dan setiap sel pada saatnya akan mengalami mutasi pada saat proses penuaan, sebagai contoh adanya mutasi dari sel-sel kelamin. (Manangkot, Sukawana dan Witarsa, 2016).

Peningkatan populasi lansia menimbulkan berbagai permasalahan fisik dan psikologis oleh karena lansia mengalami penurunan secara fisiologis dan psikologis. Proses penurunan tersebut menyebabkan lansia sulit untuk melakukan aktivitas sehari-hari secara mandiri dan tergantung pada orang lain. Keterbatasan dalam melakukan aktivitas sehari-hari akan menimbulkan penurunan fungsi kognitif, terjadinya penyakit degeneratif, ketidakmampuan fisik, nyeri, gangguan tidur, isolasi sosial, dan kepuasan hidup dapat menurunkan kualitas hidup lansia. Banyak lansia yang depresi, sulit beradaptasi dengan proses penuaan, merasa sendirian, frustasi, dan kehilangan kepercayaan diri sehingga mempengaruhi kualitas hidup mereka. (Martinson, 2015).

Prevalensi depresi lansia diatas 65 tahun menurut WHO sekitar 10-20\% (Njoto,2014). Depresi merupakan salah satu gangguan suasana hati atau gangguan afektif. Menurut Riset Kesehatan Dasar (2012) dan Njoto (2014), seseorang yang mengalami depresi menyebabkan perubahan emosional, penurunan motivasi, gangguan fungsi dan perilaku motorik, serta fungsi kognitif. Depresi pada lansia lebih sulit dideteksi, karena penyakit fisik pada lansia sering mengacaukan gambaran depresi. Lansia sebagian besar menutupi rasa sedihnya dengan menunjukkan aktivitas yang lebih aktif, padahal gejala depresi yang muncul sering ditutupi sehingga mengakibatkan meningkatnya prevalensi depresi pada lansia.

Lansia di Indonesia memiliki UHH yang lebih panjang karena pelayanan kesehatan yang semakin membaik. Struktur ageing population merupakan cerminan dari semakin tingginya rata-rata UHH penduduk Indonesia. Tingginya UHH merupakan salah satu indikator keberhasilan pencapaian pembangunan nasional terutama di bidang kesehatan. Sejak tahun 2004 - 2015 memperlihatkan adanya peningkatan 
UHH di Indonesia dari 68,6 tahun menjadi 70,8 tahun dan proyeksi tahun 2030-2035 mencapai 72,2 tahun (Kementrian Kesehatan RI, 2016).

Kebugaran jasmani pada lansia umumnya relatif rendah karena secara fisiologis lansia akan mengalami penurunan fungsi sel. (National Institute for Health and Clinical Excellence, 2010 dan Sundari, Suhadi, Maryati, 2014). Penurunan fungsi sel tersebut menyebabkan menurunnya sumber energi yang berasal dari metabolisme aerobik dan anaerobik pada saat melakukan aktivitas sehari-hari (Muzail dan Martini,2014). Penurunan metabolisme pada lansia lebih dominan pada penurunan kemampuan metabolisme aerobik. Bertambahnya usia lansia menyebabkan penurunan derajat kebugaran jasmani sekitar $30-50 \%$ pada usia 70 tahun. Penurunan kebugaran jasmani tersebut disebabkan menurunkan aktivitas fisik sehari-hari yang dilakukan lansia (Bellinger and Minahan, 2015). Penurunan aktivitas fisik pada lansia akan menyebabkan perubahan pada tingkat biomolekuler antara lain penurunan ekspresi protein plasma BDNF (Gorska-Ciebiada , Saryusz-Wolska, Borkowska ,Ciebiada, Loba, 2015 ).

Olahraga pada usia dewasa muda dapat mempertahankan aliran darah keseluruh tubuh yang optimal dan meningkatkan penghantaran nutrisi ke otak. Olahraga dapat memfasilitasi metabolisme neurotransmiter, menghasilkan faktor neurotropik yang merangsang neurogenesis. Selain itu olahraga meningkatkan stimulasi aktivitas molekuler dan selular di otak dan menjaga plastisitas otak sehingga fungsi kognitif meningkat (Maryam et al, 2011).

Tiga mekanisme yang berperan dalam peningkatan fungsi kognitif yaitu angiogenesis pada otak, perubahan synaptic reverse dan menghilangnya penumpukan amiloid. (Maryam et al 2011), Mekanisme pertama terjadinya peningkatan fungsi kognitif adalah angiogenesis pada otak. Angiogenesis merupakan pertumbuhan pembuluh darah baru yang terjadi di otak, baik dalam kondisi sehat maupun sakit. Proses angiogenesis dimulai dengan proses inisiasi, yaitu dilepaskannya enzim protease dari sel endotel yang teraktivasi setelah berolahraga . Setelah proses inisiasi terjadi pembentukan pembuluh darah, proses ini diawali dengan terjadinya degradasi matriks ekstraseluler, migrasi dan proliferasi sel endotel, serta pembuatan matriks ekstraseluler baru. Setelah pembentukan pembuluh darah, proses selanjutnya akan terjadi maturasi/stabilisasi pembuluh darah.

Mekanisme kedua terjadinya peningkatan fungsi kognitif adalah perubahan synaptic reverse. Sinaps berfungsi menyalurkan rangsang dari satu sel saraf ke sel saraf lain melalui proses biokimia dan biolistrik. Proses biokimia dan biolistrik terjadi karena adanya rangsangan neurotransmiter pada neuron pascasinaps. Olahraga yang dilakukan secara rutin menyebabkan pengulangan penyaluran rangsangan secara kontinyu akan memberikan stimulasi kepada otak untuk merekam informasi yang ada sehingga fungsi kognitif akan meningkat.

Mekanisme ketiga terjadinya peningkatan fungsi kognitif adalah menghilangnya penumpukan amiloid. Amiloid polipeptida atau amilin merupakan senyawa yang normalnya di dalam granul insulin dan ikut disekresikan bersama insulin. Amilin bersifat sitotoksik menyebabkan masuknya kalsium dalam sel $\beta$ dan membentuk agregasi intrasel. Agregasi intrasel tersebut menyebabkan terjadinya penumpukan amiloid yang berpengaruh terhadap fungsi kognitif. Apabila olahraga dilakukan 
secara rutin maka amiloid tidak disekresikan bersama insulin sehingga zat sitotoksik ini tidak menumpuk bahkan menghilang sehingga tidak akan mengganggu fungsi kognitif .

Suatu studi menjelaskan bahwa ada olahraga dapat mempengaruhi fungsi kognitif melalui perubahan kadar BDNF, IL-6, TNF- $a$, IL-8, IL-15, IGF-1. Olahraga menyebabkan hipertrofi hipokampus yang berfungsi melindungi terhadap degenerasi neuronal. Selain itu olahraga dapat meningkatkan kadar BDNF sehingga terjadi neurogenesis. Oleh karena olahraga akan meningkatkan $B D N F$, maka akan ditemukan pula peningkatan kadar Insulin Like Growth Factor -1 (IGF-1). Peningkatan kadar BDNF dan IGF-1 akan meningkatkan neurogenesis dan fungsi kognitif. Peningkatan kadar ini akan meningkatkan neurogenesis dan fungsi kognitif (Maryam et al, 2011).

Respon BDNF terhadap olahraga yang dilakukan terbatas pada sistem motorik dan sensorik dari otak seperti serebellum, area korteks primer antara lain basal ganglia. $B D N F$ merupakan kandidat yang lebih baik dalam memediasi manfaat jangka panjang terhadap otak, meskipun faktor-faktor neurotrofik lain seperti NGF $\mathcal{E}$ FGF-2 juga diindukasi di hipokampus sebagai respon terhadap olahraga, namun peningkatannya hanya sesaat dan tidak nyata dibandingkan BDNF (Maryam et al, 2011).

BDNF adalah protein yang dikodekan oleh gen BDNF. BDNF merupakan neurotopik (Growth Factor) yang merupakan bagian dari Nerve Growth Factor (NGF) . BDNF ditemukan di otak, sistem saraf perifer dan plasma darah. Gen ini berfungsi untuk meningkatkan neurogenesis serta mendukung kemampuan neuron untuk bertahan hidup. Gen ini aktif di area korteks, pre-korteks dan lebih dominan di hipokampus. Proses neurogenesis terjadi apabila terdapat stimulasi dari neurotropik dan BDNF inilah yang paling aktif menstimulasi dan mengendalikan proses neurogenesis (Maryam et al, 2011).

Menurut Maryam et al, (2011), bertambahnya usia menyebabkan penurunan ekspresi protein plasma $B D N F$ di hipokampus dan korteks temporal. BDNF dan ekspresi reseptor spesifiknya (Trk B) di hipokampus menurun seiring dengan bertambahnya usia, namun $m R N A B D N F$ tidak akan mengalami perubahan.

Lansia dengan tingkat aktivitas fisik yang aktif memiliki fungsi kognitif normal dibandingkan lansia yang memiliki aktivitas fisik yang kurang. Hasil penelitian pada 51 orang lansia berusia $\geq 60$ tahun yang terdiri dari 13 orang laki-laki dan 38 orang perempuan. Hasil penelitian menggunakan rancangan cross sectional menunjukkan, lansia yang aktif sebesar $29,4 \%$ dan lansia yang tidak aktif sebesar $70,6 \%$. Lansia yang memiliki fungsi kognitif yang relatif baik sebesar $82.4 \%$ dan lansia yang mengalami penurunan fungsi kognitif sebesar $17.6 \%$. Menggunakan uji chi-square dilaporkan lansia yang memiliki aktivitas fisik yang aktif berkolerasi positif dengan fungsi kognitif $(\mathrm{p}=0.044, \mathrm{p}<0.05)$ (Ihara et al,2016).

Penurunan ekspresi gen BDNF di otak dan plasma darah dapat dijadikan sebagai prediktor depresi pada lansia. Olahraga dengan intensitas sedang dapat dijadikan sebagai intervensi untuk menstimulasi otak meningkatkan kadar BDNF. Olahraga selain meningkatkan $B D N F$ dan fungsi kognitif, berdampak juga terhadap neurogenesis yaitu terjadinya perluasan serabut saraf, peningkatan jumlah sinap 
dan pembuluh darah kapiler serta peningkatan perfusi jaringan otak. Olahraga menyebabkan tekanan darah sistolik menjadi normal , kadar lipoprotein meningkat, serta produksi endhotelial Nitric Oxide (eNO) meningkat. (Ihara et al ,2016).

\section{Metode}

1. Tahapan kajian yang gunakan untuk menyelesaikan permasalahan pengabdian Tahapan kegiatan yang dilakukan untuk merealisasikan kegiatan pendidikan kesehatan adalah sebagai berikut :

a. Konsultasi dengan pakar kesehatan jiwa (Lynna Lidyana, dr., SpKJ Shelly,dr.,Sp.KJ.,Sp.Ak.,M.Si.,Ph.D) membahas mengenai instrumen MMSE dan GDS-15

b. Koordinasi dengan pimpinan panti atau penentu kebijakan mengenai waktu yang tepat untuk melakukan penyuluhan kesehatan dengan petugas panti, pramuwhreda, lansia dan perawat panti

c. Koordinasi dengan tim mengenai persiapan penyuluhan kesehatan (metode, media dan bahan yang diperlukan).

d. Penyuluhan kesehatan mengenai gejala depresi pada lansia kepada petugas panti

e. Penyuluhan kesehatan mengenai gejala depresi pada lansia kepada pramuwhreda

f. Penyuluhan kesehatan mengenai kondisi fisik dan psikis yang dialami lansia kepada lansia

g. Pelatihan dan pendampingan pengkajian kepada lansia dengan menggunakan instrumen MMSE dan GDS-15.

2. Analisis data yang digunakan.

Derajat kebugaran jasmani pada lansia umumnya relatif rendah karena secara fisiologis lansia akan mengalami penurunan fungsi organ tubuh. Penurunan fungsi organ tubuh tersebut menyebabkan menurunnya kemampuan metabolisme aerobik pada saat melakukan aktivitas sehari-hari. Penurunan kemampuan metabolisme pada lansia lebih dominan dengan penurunan kemampuan metabolisme aerobik. Bertambahnya usia lansia menyebabkan penurunan derajat kebugaran jasmani sekitar 30-50\% pada usia 70 tahun. Bertambah cepatnya penurunan derajat kebugaran jasmani erat kaitannya dengan semakin berkurangnya aktivitas fisik sehari-hari yang dilakukan lansia.

Pada lansia sering ditemukan masalah depresi. Prevalensi depresi lansia diatas 65 tahun menurut WHO sekitar 10-20\%.1-3 Depresi merupakan salah satu gangguan suasana hati atau gangguan afektif. Seseorang yang mengalami depresi menyebabkan perubahan emosional, penurunan motivasi, gangguan fungsi dan perilaku motorik, serta fungsi kognitif. Depresi pada lansia lebih sulit dideteksi, karena penyakit fisik pada lansia sering mengacaukan gambaran depresi. Lansia sebagian besar menutupi rasa sedihnya dengan menunjukkan aktivitas yang lebih aktif, padahal gejala depresi yang muncul sering ditutupi sehingga mengakibatkan meningkatnya prevalensi depresi pada lansia. Instrumen untuk mengukur tingkat depresi pada lansia adalah Geriatric Depression Scale (GDS-15). 
Kesulitan untuk menegakkan depresi pada lansia diperlukan pengalaman dan keahlian khusus terutama bagi perawat yang bekerja di BPSTW Ciparay, oleh karena itu diperlukan pelatihan dan bimbingan langsung kepada perawat untuk menggunakan instrumen MMSE dan GDS-15 sehingga prevalensi depresi di panti dapat dicegah dan lansia yang mengalami depresi tingkat berat dapat dilakukan rujukan kepada pelayanan kesehatan untuk mendapatkan pengobatan dan pemulihan.

Selain diperlukan adanya pelatihan dan pendampingan kepada perawat panti, keterlibatan petugas panti dan pramuwhreda yang bertanggung jawab di setiap wisma juga diperlukan untuk mengenal gejala depresi pada lansia sehingga adanya kerjasama antara semua elemen yang terkait. Lansia yang terjaring depresi juga menjadi sasaran kegiatan PPM sehingga dirinya mampu mengenal masalah yang dirasakan dirinya dan mampu mengingatkan lansia lain yang membutuhkan.

Kerangka pemecahan masalah diatas dapat digambarkan sebagai berikut :

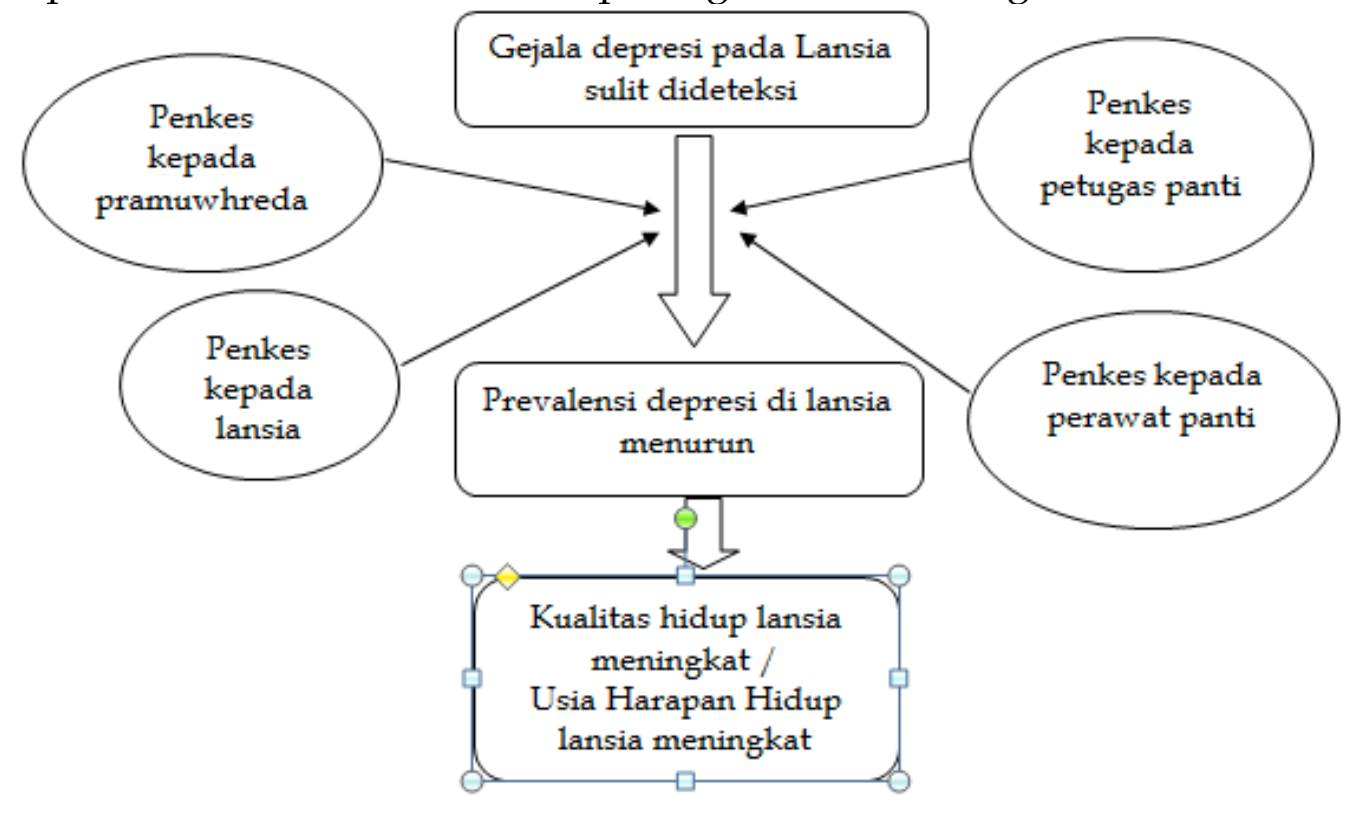

Sumber : Irawan, H.(2013).

Gambar 1. Kerangka pemecahan masalah

\section{Hasil dan Pembahasan}

1. Konsultasi dengan pakar kesehatan jiwa (Lynna Lidyana, dr., SpKJ Shelly,dr.,Sp.KJ.,Sp.Ak.,M.Si.,Ph.D) membahas mengenai instrumen MMSE dan GDS-15.

Kegiatan ini dilaksanakan pada tanggl 13 juli 2018 di Rumah Sakit Pendidikan UNPAD, tim peneliti mendiskusikan mengenai instrumen MMSE yang perlu dibuatkan pedoman atau panduan bagi pemakainya sehingga memiliki persepsi yang sama untuk setiap penggunanya. Perubahan yang dicapai khalayak sasaran: Perawat panti mampu mengaplikasikan instrumen dengan baik kepada lansia yang ada dibawah tanggung jawabnya serta berencana untuk rutin melakukan 
pengkajian kepada lansia yang baru di panti sebagai bagian dari asuhan keperawatan .

2. Koordinasi dengan pimpinan panti atau penentu kebijakan mengenai waktu yang tepat untuk melakukan penyuluhan kesehatan dengan petugas panti, pramuwhreda, lansia dan perawat panti.

Kegiatan ini dilakukan melalui media WhatApps untuk koordinasi waktu yang tepat dalam memberikan penyuluhan kesehatan kepada petugas panti, pramuwhreda, lansia dan perawat panti.

3. Koordinasi dengan tim mengenai persiapan penyuluhan kesehatan (metode, media dan bahan yang diperlukan).

Kegiatan ini dilakukan pada tanggal 3 Agustus 2018 di Rumah Sakit Pendidikan UNPAD, tim peneliti mendiskusikan mengenai persiapan penyuluhan kesehatan yang terdiri dari metode dan media yang tepat untuk sasaran. Metode dan media yang dilakukan adalah interaktif antara penyuluh dngan sasaran dean menggunakan media power point dan video yang mendukung terhadap ketercapaian tujuan. Bahan yang digunakan dalam bentuk modul, buklet yang mendukung disesuaikan dengan sasaran, yaitu untuk lansia diberikan buklet yang berisi materi yang disampaaikan dengan menggunakan tulisan yang lebih besar sehingga dapat dibaca oleh lansia. Bagi petugas panti dan pramuwhreda diberikan bahan berupa power point dan video yang mendukung dan untuk perawat diberikan bahan instrumen beserta panduan atau pedoman yang telah dibuat.

Perubahan yang dicapai khalayak sasaran :

Penggunaan metode, media, bahan yang tepat memberikan kemampuan petugas panti, pramuwhreda, lansia dan perawat panti lebih interaktif dan berpartisipasi dalam proses penyuluhan. Selain itu adanya diskusi lanjutan diluar kegiatan penyuluhan mengenai kendala atau hambatan yang mungkin terjadi dilapangan serta berbagai solusi yang dapat dilakukan.

4. Penyuluhan kesehatan mengenai gejala depresi pada lansia kepada petugas panti Kegiatan ini dilakukan pada tanggal 8 Agustus 2018 di aula BPSTW.

Perubahan yang dicapai khalayak sasaran :

Sebagian besar petugas panti antusias dalam mengikuti penyulusan kesehatan karena dianggap belum pernah mendapatkan informasi mengenai depresi pada lansia.

Petugas panti berencana akan memperhatikan kondisi emosional lansia yang tinggal di panti dan melakukan kooordinasi dengan perawat dan membantu alam proses rujukan bila diperlukan kepada pelayanan kesehatan.

5. Penyuluhan kesehatan mengenai gejala depresi pada lansia kepada pramuwhreda Kegiatan ini dilakukan pada tanggal 9 Agustus 2018 di aula BPSTW.

Perubahan yang dicapai khalayak sasaran :

Sebagian besar pramuwhreda antusias dalam mengikuti penyulusan kesehatan karena dianggap belum pernah mendapatkan informasi kesehatan selama menjadi pramuwhreda di panti. Peserta menginginkan adanya informaasi kesehatan secara umum yang terjadi pada lansia secara berkelanjutan sehingga mampu 
menjadi bagian penting dalam meningkatkan kesehatan lansia di panti dan kualitas hidup lansia.

Pramuwhreda berencana akan memperhatikan kondisi emosional lansia yang tinggal di panti dan melakukan kooordinasi dengan perawat apabila mendapatkan gejala depresi pada lansia selama bekerja di setiap wisma.

6. Penyuluhan kesehatan mengenai kondisi fisik dan psikis yang dialami lansia kepada lansia.

Kegiatan ini dilakukan pada tanggal 20 Agustus 2018 di Aula BPSTW.

Perubahan yang dicapai khalayak sasaran :

Lansia sebagian besar sangat bersemangat mendapatkan informasi menganai perubahan fisik dan psikis yang dialami pada usia nya termasuk kemungkinan adanya masalah emosional (depresi). Pada saat penyuluhan, ada beberapa lansia yang bertanya mengenai materi yang disampaikan termasuk memberikan tanggapan saat penyuluh meminta tanggapan dan masukan. Untuk meningkatkan pertisipasi aktif lansia, penyuluh memberikan door prize berupa pemberian biskuit kepada 5 orang lansia yang dapat menjawab pertanyaan penyuluh. Kelima lansia dapat menjawab dengan baik dan benar semua pertanyaan penyuluh terkait dengan masalah fisik dan psikis yang dialami lansia.

7. Pelatihan dan pendampingan pengkajian kepada lansia dengan menggunakan instrumen MMSE dan GDS-15.

Kegiatan ini dilakukan pada tanggal 17 Juli 2018 di klinik perawat BPSTW dan wisma.

Instrumen MMSE merupakan alat bantu untuk mengkaji fungsi kognitif pada lansia. Penggunaan instrumen ini sebagai syarat untuk menggunakan instrumen GDS-15 pada lansia yang memiliki gejala depresi. Apabila lansia memiliki nilai MMSE dibawah normal $(<24)$, maka lansia tersebut tidak perlu dilakukan tes GDS-15. Melihat pentingnya petugas kesehatan (perawat panti) untuk mengukur fungsi kognitif pada lansia secara rutin, maka tim berupaya melakukan pelatihan dan pendampingan penggunaan instrumen MMSE tersebut. Untuk memudahkan dalam pelatihan, tim membuat panduan bagian perawat dalam menggunakan instrumen MMSE dan GDS-15 dan informed consent yang akan disiapkan untuk lansia. (terlampir)

Mild Cognitive Impairment (MCI) adalah istilah yang digunakan untuk mendeskripsikan pasien yang memiliki gangguan kognitif, namun tidak memenuhi kriteria demensia dan belum tentu akan berkembang menjadi demensia. Gangguan kognitif merupakan salah satu komplikasi jangka panjang dari stroke. MMSE, sebagai alat deteksi dini yang rutin dipergun akan, memiliki sensitivitas yang rendah untuk mendeteksi gangguan kognitif, terutama $M C I$ ) MoCA-Ina dikatakan memiliki sensitivitas yang lebih tinggi. Proporsi MCI dengan menggunakan MMSE adalah sebesar 31,03\%, sedangkan dengan MoCA-Ina sebesar $72,41 \%$. Perbedaan proporsi tersebut bermakna secara statistik (uji Fisher's exact, $\mathrm{p}=0,033)$. 
Perubahan yang dicapai khalayak sasaran :

1. Seluruh perawat sangat antusias mendapatkan informasi mengenai MMSE dan GDS-15 dan berkeinginan untuk mengaplikasikan pada lansia di panti. Pelatihan disertai dengan simulasi langsung kepada perawat sehingga perawat akan merasakan prosesnya (hambatan dan solusi yang dapat dilakukan).

2. Pendampingan perawat saat melakukan pengkajian terhadap lansia juga dilakukan di wisma tempat lansia tinggal sehingga secara bersama-sama dapat di evaluasi ketercapaian kegiatan dan upaya yang harus dilatih untuk menyempurnakan asuhan keperawatan.

Kegiatan pendampingan dilakukan pada tanggal 18-19 Juli 2018 kepada 37 lansia yang memiliki gejala depresi. Diantara 37 lansia terdapat 7 orang lansia yang memiliki MMSE tidak normal sehingga ketujuh lansia tersebut tidak dilanjukan dengan pengkajian GDS-15. Pendampingan dilakukan di beberapa wisma yaitu : melati, flamboyan, sedap malam, soka, dahlia, teratai, tulip, cempaka, ros, bougenvile, wijayakusuma dan katlea. Ketiga puluh lansia kemudian diberikan instrumen GDS-15 dan didapatkan 20 lansia depresi ringan dan 20 lansia depresi sedang.

\section{Simpulan dan Rekomendasi}

Untuk mencapai tujuan program PPM yaitu semua elamen di BPSTW dapat mengidentifikasi atau mendeteksi dini gejala depresi dan penurunan fungsi kognitif pada lansia maka perlu adanya keberlanjutan kegiatan yang telah dilakukan Rencana keberlanjutan program sebagai berikut : Konsultasi dengan pakar kesehatan jiwa (tim peneliti) lebih ditingkatkan dalam berbagai media walaupun adanya keterbatasan untuk bisa bertemu di waktu dan tempat yang bersamaan ; Koordinasi perlu ditingkatkan dengan petugas panti, pramuwhreda dan perawat panti untuk mendukung pelaksanaan program kegiatan penelitian dan pengabdian masyarakat ; Penyuluhan kesehatan berkelanjutan kepada petugas panti, pramuwhreda mengenai kondisi kesehatan yang terjadi pada lansia dan upaya yang dapat dilakukan untuk mendukung peningkatan kesehatan dan kualitas hidup lansia ; Penyuluhan kesehatan berkelanjutan kepada lansia mengenai upaya pencegahan agar tidak mengalami depresi dan penuruan fungsi kognitif melalui keterlibatan penuh terhadap kegiatan yang dilakukan di panti yang sudah rutin dilakukan ; Pendampingan berkelanjutan kepada perawat sehingga terjalin koordinasi yang baik dalam mensukseskan peningkatan kesehatan lansia di panti. Selain itu sebagai media kerjasama dalam membuat program penyuluhan kesehatan terhadap lansia yang disesuaikan dengan kebutuhan lansia.

\section{Acknowledgements}

Ucapan terima kasih kepada Direktorat Penelitian dan Pengabdian Masyarakat Universitas Padjadjaran melalui hibah Riset Fundamental Unpad tahun 2018 yang telah berkontribusi dalam pendanaan kegiatan Penelitian dan Pengabdian Masyarakat. 


\section{Daftar Pustaka}

American Psychiatric Association. (2015). Diagnostic and Statistical Manual of Mental Disorders (4th ed.). (Text Revision). Washington, DC: American Psychiatric Press.

Bellinger, P. M., \& Minahan, C. L. (2015). European Journal of Sport Science, 16(7), 829836. doi : 10.1080/17461391.2015.1120782

Bhayu, I. A., Ratep, N., \& Westa, W. (2015). Gambaran faktor-faktor yang mempengaruhi tingkat depresi pada lanjut usia di wilayah kerja Puskesmas Kubu II Januari-Februari 2014. E-Jurnal Med Udayana, 4(1), 1-14.

Darmojo, B. (2014). Buku Ajar Boedhi-Darmojo Geriatri (Ilmu Kesehatan Usia Lanjut), V. Jakarta: Badan Penerbit FKUI.

Depkes RI., Riset Kesehatan Dasar. (2012). Penelitian dan Pengembangan Kesehatan Departemen Kesehatan RI. Badan Litbangkes RI. Diperoleh dari http://www.diskes.jabarprov.go.id

Gorska-Ciebiada, M., Saryusz-Wolska, M., Borkowska, A., Ciebiada, M., \& Loba, J. (2015). Serum levels of inflammatory markers in depressed elderly patients with diabetes and mild cognitive impairment. PLoS One [Internet], 10(3), 1-17. Retrieved from: http://dx.doi.org/10.1371/journal.pone.0120433

Hayashi, J., \& Decherrie, L. (2016). Geratric Home-Based Medical Care: Principle and Practice. Springer , 125-30.

Ihara, K., Yoshida, H., Jones, P. B., Hashizume, M., Suzuki, S., Ishijima, H. (2016). Serum BDNF levels before and after the development of mood disorders: a case-control study in a population cohort. Translational Psychiatry, 6, 782. doi:10.1038/tp.2016.47

Irawan, H.(2013). Gangguan Depresi pada Lanjut Usia. CDK-210, 40(11), 815-9.

Kementrian Kesehatan Republik Indonesia. Pusat Data dan Informasi Kementrian Kesehatan RI. (2016). Situasi dan Analisa Lanjut Usia. Jakarta Selatan.

Manangkot, M. V., Sukawana, I. W., Witarsa, M. S. (2016). Pengaruh Senam Lansia terhadap Keseimbangan Tubuh pada Lansia di Lingkungan Dajan Bingin Sading. Jurnal Keperawatan Community of Publishing in Nursing (COPING) NERS. Januari - April Ed.

Martinson, M., Berridge, C., Bengtson, V. L., Silverstein, M., Putney, N. M., Gans, P. (2009). D. Handbook of theories of aging. (2nd ed). Gerontologist, 55, 58-69 New York: Springer Publishing Company.

Lestari, I., Mistivani, C. M., Rumende., \& Kusumaningsih, W. (2017). Comparison between mini mental state examination (MMSE) and Montreal cognitive assessment Indonesian version (MoCA-Ina) as an early detection of cognitive impairments in post-stroke patients. IOP Conf. Series: Journal of Physics: Conf. Series, 884, 012153. doi :10.1088/1742-6596/884/1/012153

Martinson, M. \& Berridge, C. (2015). Successful aging and its discontents: A systematic review of the social gerontology literature. Gerontologist, 55(1), 5869.

Maryam, R. S., Ekasari, M., Jubaedi, A., Batubara, I., \& Rosidawati. (2011). Mengenal Usia Lanjut dan Perawatannya. Jakarta: Salemba Medika. 
Maurer, D. (2012). Screening for Depression. Am Fam Physician, 2, 139-42.

Mura, C. (2013). Physical Activity in Depressed Elderly. A Systematic Review. Clinical Practice E Epidemiology in Mental Health, 9, 125-135.

Muzail, M. S., \& Martini, R. S. (2014). Hubungan Antara Tingkat Aktivitas Fisik dengan Fungsi Kognitif pada Usila di Kelurahan Jati Kecamatan Padang Timur. Jurnal Kesehatan Andalas, 3(2).

National Institute for Health and Clinical Excellence. (2010). Depression: the treatment and management of depression in adults [updated edition]. Leicester, UK: British Psychological Socaity .

Njoto, E. N., (2014). Mengenali Depresi pada Usia Lanjut Penggunaan Geriatric Depression Scale (GDS ) untuk Menunjang Diagnosis. CDK-217 , 41(6), 472.

Sundari, M. J., Suhadi., Maryati. (2014). Pengaruh Senam Lansia terhadap Penurunan Tekanan Darah Lansia di Panti Wreda Usia Bethany Semarang. Diperoleh dari Ejournal.stikestelogorejo.ac.id 